\section{The Arabic Frame Tradition}

To the Editor:

When Katharine Slater Gittes says, in "The Canterbury Tales and the Arabic Frame Tradition" (PMLA 98[1983]:237-51), "The pilgrims are innocent purveyors of Chaucer's sophisticated design" (247), she gives happy and concise expression to one of the basic patterns in the work. The characters are apparently free of the author's control, yet what they will inevitably creates meaning. She later suggests that Chaucer "plays with disorder, giving the impression that the arrangement is more arbitrary than it really is" (247).

The main thrust of her article, however, discounts the element of order and emphasizes instead the open-endedness. This open-endedness she attributes to Arabic influence and especially to the influence of Petrus Alfonsi's Disciplina Clericalis. She points out that several of the tales are incomplete, that the number of tales and the number of pilgrims are contradictory in different parts of the work, and that the pilgrims never even reach Canterbury. "[D]isrupted expectations of order and symmetry ... put to rest any notion that the scope of the work is foreseeably contained."

Much of this "open-endedness" results from the fragmentary state of the Canterbury Tales at Chaucer's death. Fifteenth-century editors did their best to conceal this incompleteness, and modern critics have accepted too readily the impression they strove to create. The two endings envisaged in the text, though contradictory, would each have brought the work to a clear conclusion. In his prologue the Parson, employing the very device by which the Host has distracted the pilgrims from religious purpose, that is, the storytelling, sets himself the task of showing the way "Of thilke parfit glorious pilgrimage, / That highte Jerusalem celestial." The setting sun, the "thropes ende," the lack of "no tales mo than oon," the fulfillment of the host's "sentence" and "decree" as well as almost all his "ordenaunce," the Parson's resolve "To knytte up al this feeste," the pilgrims' sense of the propriety of ending in "som vertuous sentence" all stress closure. In my view, the treatise on repentance and the seven deadly sins, with the attached retraction, was never intended by Chaucer to bring the Canterbury Tales to an end. But fifteenth-century editors saw in it a fitting conclusion, and most modern readers have agreed. Although with the retraction "the framing story disappears before the work ends" (245) - as it does in the Disciplina-the result is a judgment on the whole, a rejection of aesthetic values, a thorough closure; nothing can conceivably be added.

The ending envisaged in the General Prologue, which puts much greater emphasis on the frame story, would have given the completed Canterbury Tales an even more decisive closure. The supper at the Tabard with the Host deciding which of the pilgrims had told the best stories would have called for an implicit review by each reader, a judgment of the judgment, as it were. It might well have involved comment on the Host's verdict by the pilgrims. It would have emphasized ending by place (a full circle), time (completion of the pilgrims' fellowship), and action (evaluation of what had transpired).

The contradictions implicit in the endings, like the explicit contradictions in number of tales and number of pilgrims, result from the evolution of the plan for the whole as Chaucer worked on it rather than from intentional open-endedness. But the unexpected within the whole-interruptions by pilgrims, challenges of the Host's authority, intrusions by men like the Canon and his Yeoman-were an important part of Chaucer's design from the beginning. The focus on the unit, which as Katharine Gittes points out may well stem from the general Arabic influence on medieval thought, is balanced by attention to the interrelation of parts. Each tale has importance in itself. But the portraits provide an audience, any member of which may respond.

One minor point. Although it is true that Chaucer mentions Petrus Alphonsi five times in the Canterbury Tales, all five references occur in the Melibeus in passages translated from the French of Renaud de Louens; they therefore do not imply direct influence.

Charles A. OWen, $J_{R}$.

University of Connecticut, Storrs

\section{To the Editor:}

Katherine Slater Gittes' article "The Canterbury Tales and the Arabic Frame Tradition" is an important reminder to medievalists that we have too often neglected the Arabic component of medieval culture. Vast worlds of Arabic intellectual achievement remain unexplored by most of us. The neglected territory is far vaster yet, however, for it is not only the Arabic frame tale that accepts incompletion or openness as an aesthetic value, in contrast to the (stereotypical) Western concept of closed unity. Indeed, as has been demonstrated from an anthropological perspective by researchers such as Dorothy Lee ("Lineal and Nonlineal Codi- 
fications of Reality," Psychosomatic Medicine 12[1950]:89-97) and argued in other literary contexts by, for example, Tzvetan Todorov, it is the supposed Western preoccupation with linear unity that is peculiar. Much of the rest of the world does not, and has not, perceived reality in that way.

Even in the West, one might point out, the passion for linear order and completion is only a fluctuating phenomenon. Plato, Aristotle, and Horace have not spoken for us all.

To return to Chaucer: the aesthetic qualities of incompletion need not be related primarily to the Arabic frame tale as a genre. They are inherent in Chaucer's world view whether he is writing a frame tale or not (unless we are reduced to claiming that all "incomplete" narratives thereby belong to the genre of the Arabic frame tale). No Chaucerian work remains more elusively incomplete, for example, than Troilus and Criseyde. Whatever became of the heroine? Chaucer's follower Henryson thought that we needed to know and therefore completed her story (in the Testament of Cressid), but Chaucer left the outcome unstated. In fact, embedded components, arbitrary transitions, unresolved questions, and juxtaposed but apparently unrelated ingredients, as well as what Gittes calls "the need to keep structural boundaries open," are recurrent not only in Chaucer's work but in many aspects of Western medieval culture. Even the medieval cathedral, which Gittes cites as symbolic of "closed" structures, was in practice often open-ended in form and function, receptive to added sections or repeated expansions or, in the other direction, used indefinitely without ever being what we would call completed.

What we need is a fundamental reassessment of medieval aesthetics-broadened far beyond the linear tradition of unity that we have mistakenly assumed predominated-rather than a special correlation of Chaucer's assumptions to an Arabic genre that he presumably did not know in any Arabic form. Some of that genre's presuppositions were so broadly shared as to be visible nearly everywhere, once the assumption of linearity is no longer permitted to limit our view.

\section{Caroline D. Eckhardt \\ Pennsylvania State University}

\section{Reply:}

Charles A. Owen, Jr., makes a thoughtful point when he says that much of the open-endedness in the Canterbury Tales results from its "fragmentary state" at Chaucer's death. Certainly the contradictions between the "two endings envisaged in the text" could support the notion that the work is fragmentary; evidence in both the Parson's Prologue and in the General Prologue can easily be taken to indicate that Chaucer intended "decisive closure." The contradiction may also indicate, however, that Chaucer did not consider decisive closure a strict necessity. When we look at the whole frame-narrative tradition, we see that most frame narratives contain intimations of decisive closure, but in spite of such intimations, these works are never closed but remain open at the end (and throughout). Thus it is likely that Chaucer, like other writers of frame narratives, made the pretense of closing but never really intended to reach a firm and final close. Owen sees the work as fragmentary because it is openended, but he fails to see the other argument that the openness at the end and elsewhere may be part of the Canterbury Tales' structural plan. In other words, the frame-narrative tradition provides a key to understanding Chaucer's structure and organization.

Owen's suggestion that Chaucer may not have been familiar with the Disciplina Clericalis is provocative; certainly we can never know with certainty what Chaucer read. The existence of over sixty surviving manuscripts of Petrus Alfonsi's work, however, demonstrates that the Disciplina enjoyed tremendous popularity in the Middle Ages (Dorothee Metlitzki, The Matter of Araby in Medieval England [New Haven: Yale Univ. Press, 1977], 96-97). Though the issue can never be decided, the broad availability of the book implies that Chaucer probably had access to it.

Caroline D. Eckhardt is certainly right that we need a "fundamental reassessment of medieval aesthetics." The purpose of my essay, however, is less ambitious: to discuss the influence of one tradition, the frame narrative, on one medieval writer. I think there is ample evidence that within this range (relatively modest in scope) Chaucer responded to the Arabic tradition. I am not convinced that the structure of Troilus and Criseyde is comparable to that of the Canterbury Tales. Troilus and Criseyde has a consistent story line throughout, the central concern is the relationship between the two main characters, and their relationship is thoroughly and decisively finished when the work ends. Though I agree that we wonder what happens to Criseyde after Troilus dies, the work does not have the kind of ambiguous open-endedness that we find in the Canterbury Tales.

Some characteristics of the frame narrative appear in many medieval works other than frame narratives. Many of the major medieval landmarks - Sir Gawain and Piers Plowman, for instance- 